\title{
Behavioral Effects of a Synthetic Agonist Selective for Nociceptin/Orphanin FQ Peptide Receptors in Monkeys
}

\author{
Mei-Chuan Ko*,',2, James H Woods', William E Fantegrossi ${ }^{3}$, Chad M Galuska ${ }^{4}$, Jürgen Wichmann ${ }^{5}$ \\ and Eric P Prinssen ${ }^{5}$
}

'Department of Pharmacology, University of Michigan, Ann Arbor, MI, USA; ${ }^{2}$ Department of Psychology and Institute of Neuroscience, National Cheng Chi University, Taipei, Taiwan; ${ }^{3}$ Department of Pharmacology and Toxicology, University of Arkansas for Medical Sciences, Little Rock, AR, USA; ${ }^{4}$ Department of Psychology, College of Charleston, Charleston, SC, USA; ${ }^{5}$ F.Hoffmann-La Roche Ltd, Basel, Switzerland

\begin{abstract}
Behavioral effects of a nonpeptidic NOP (nociceptin/orphanin FQ Peptide) receptor agonist, Ro 64-6198, have not been studied in primate species. The aim of the study was to verify the receptor mechanism underlying the behavioral effects of Ro 64-6/98 and to systematically compare behavioral effects of Ro 64-6198 with those of a $\mu$-opioid receptor agonist, alfentanil, in monkeys. Both Ro $64-6198\left(0.001-0.06 \mathrm{mg} / \mathrm{kg}\right.$, s.c.) and alfentanil $\left(0.00 \mathrm{I}-0.06 \mathrm{mg} / \mathrm{kg}\right.$, s.c.) produced antinociception against an acute noxious stimulus $\left(50^{\circ} \mathrm{C}\right.$ water) and capsaicin-induced allodynia. An NOP receptor antagonist, J-I I 3397 (0.0 I-0.I mg/kg, s.c.), dose-dependently produced rightward shifts of the dose-response curve of Ro 64-6198-induced antinociception. The apparent pA 2 value of J-II 3397 was 8.0 . Antagonist studies using J-II3397 and naltrexone revealed that Ro 64-6198 produced NOP receptor-mediated antinociception independent of $\mu$-opioid receptors. In addition, alfentanil dose-dependently produced respiratory depression and itch/scratching responses, but antinociceptive doses of Ro 64-6198 did not produce such effects. More important, Ro 64-6198 did not produce reinforcing effects comparable with those of alfentanil, cocaine, or methohexital under self-administration procedures in monkeys. These results provide the first functional evidence that the activation of NOP receptors produces antinociception without reinforcing effects in primates. Non-peptidic NOP receptor agonists may have therapeutic value as novel analgesics without abuse liability in humans. Neuropsychopharmacology (2009) 34, 2088-2096; doi:I0.1038/npp.2009.33; published online II March 2009
\end{abstract}

Keywords: opioid; antinociception; self-administration; analgesic; abuse liability

\section{INTRODUCTION}

Opioid analgesics are the most effective and widely used drugs for pain management; the most clinically used opioids are $\mu$-opioid receptor agonists (Zollner and Stein, 2007). However, there are several side effects associated with the use of $\mu$-opioid agonists. These include constipation, respiratory depression, and itch/pruritus (Zollner and Stein, 2007). Importantly, the abuse liability derived from $\mu$-opioid agonists has been and remains a serious public health concern and limits the opioid analgesics' value for pain management (Cicero et al, 2007; Katz et al, 2007). Research to identify potential analgesics with fewer side effects and reduced abuse liability is pivotal to advances in health care of all individuals.

Given that the neuroanatomical and physiological aspects of opioid receptors are similar between humans and monkeys

*Correspondence: $\operatorname{Dr}$ MC Ko, Department of Pharmacology, University of Michigan Medical School, I30I MSRB III, Ann Arbor, MI 48109-5632, USA. Tel.: I 734647 3119, Fax: I 734764 7I।8;

E-mail: mko@umich.edu

Received I December 2008; revised 8 February 2009; accepted 10 February 2009
(Kuhar et al, 1973; Mansour et al, 1988; Peckys and Landwehrmeyer, 1999), the functions of opioid receptor subtypes can be investigated in nonhuman primates using a variety of behavioral assays and experimental compounds that are likely to be relevant to humans. In particular, the selfadministration assay in monkeys has been used extensively, and it provides useful information for the abuse liability of drugs in humans (Weerts et al, 2007). Depending on the experimental schedules, most abused drugs in humans have been shown to have reinforcing effects in monkey selfadministration procedures (Winger et al, 1975; Ator and Griffiths, 1987; Weerts et al, 2007). Although neither $\kappa$ - nor $\delta$-opioid agonists produce reinforcing effects, drugs in these categories do not have promising pharmacological profiles as strong analgesics because of their undesirable side effects. Centrally penetrating $\kappa$-opioid agonists' antinociceptive effects are compromised by sedation, and $\delta$-opioid agonists are weak analgesics limited by potential convulsant effects (Dykstra et al, 1987; Negus et al, 1998).

The NOP receptor, previously called the ORL1 receptor, is defined as the fourth member within the opioid receptor family by the International Union of Pharmacology (Mollereau et al, 1994; Foord et al, 2005). An endogenous peptide selective for the NOP receptor, nociceptin/orphanin 
FQ (N/OFQ), has been identified and shown to have similar actions as other opioid peptides at the cellular level (Meunier et al, 1995; Reinscheid et al, 1995). Although activation of supraspinal NOP receptors may produce hyperalgesic effects (Meunier et al, 1995; Rizzi et al, 2007), most studies have shown that activation of peripheral and spinal NOP receptors produces antinociceptive effects in a variety of pain models in rodents (Erb et al, 1997; Zeilhofer and Calo, 2003; Obara et al, 2005). Interestingly, both peripheral and spinal administration of N/OFQ produce antinociceptive effects in monkeys, indicating a potential therapeutic value of NOP receptor agonists as analgesics (Ko et al, 2002b, 2006).

The development of a selective nonpeptidic NOP receptor agonist, Ro 64-6198 (Jenck et al, 2000; Wichmann et al, 2000), and antagonist, J-113397 (Kawamoto et al, 1999), provides an opportunity to study integrated behavioral effects of a NOP receptor agonist in animals following systemic administration (Chiou et al, 2007; Shoblock, 2007). However, to date, there is no study investigating the behavioral pharmacological actions of Ro 64-6198 in primates. In particular, it is important to investigate whether Ro 64-6198 produces any reinforcing effect/abuse liability in monkey self-administration procedures. Therefore, the aim of the study was to clarify the receptor mechanism underlying Ro 64-6198-induced behavioral responses. Antinociceptive effects of Ro 64-6198 were further examined using different pain modalities and various behavioral assays were applied to systematically compare effects between Ro 64-6198 and alfentanil, a $\mu$ opioid receptor agonist, in monkeys.

\section{MATERIALS AND METHODS}

\section{Subjects}

Twenty seven adult gonadally intact male and female rhesus monkeys (Macaca mulatta) with body weights ranging between 6.6 and $11.7 \mathrm{~kg}$ were used. Twelve monkeys participated in the antinociception and itch/scratching studies, and another six monkeys participated in the respiration study. The remaining nine monkeys were used in the self-administration study. The monkeys were housed individually with free access to water and were fed approximately 25-30 biscuits (Purina Monkey Chow, product No. 5045; Ralston Purina, St Louis, MO) and fresh fruit daily. No monkey had exposure to any opioid receptor agonist or antagonist for 1 month before this study. The monkeys were housed in facilities accredited by the American Association for the Accreditation of Laboratory Animal Care. The studies were conducted in accordance with the University Committee on the Use and Care of Animals at the University of Michigan and the Guide for the Care and Use of Laboratory Animals as adopted and promulgated by the US National Institutes of Health (National Academy Press, Washington DC, revised 1996).

\section{EXPERIMENTAL PROCEDURES}

\section{Antinociception}

The warm water $\left(50^{\circ} \mathrm{C}\right)$ tail-withdrawal assay was used to evaluate thermal antinociceptive effects of the test compound (Ko et al, 1998a). Briefly, monkeys were seated in primate restraint chairs, and the lower part of their shaved tails (approximately $15 \mathrm{~cm}$ ) were immersed in a thermal flask containing water maintained at either 42, 46, or $50^{\circ} \mathrm{C}$. Tail-withdrawal latencies were measured using a computerized timer by an experimenter who was blinded to experimental conditions. In each test session, monkeys were tested once with three temperatures given in a random order, and only the $50^{\circ} \mathrm{C}$ water was tested twice to confirm the full antinociceptive effect. If the monkeys did not remove their tails within $20 \mathrm{~s}$, the flask was removed and a maximum time of $20 \mathrm{~s}$ was recorded. Test sessions began with control determinations at each temperature. Then, the test compound was administered subcutaneously by a cumulative dosing procedure with a 30 -min interinjection interval. Subsequent tail-withdrawal latencies were determined starting $20 \mathrm{~min}$ after each injection.

The NOP receptor antagonist potency of J-113397 against Ro 64-6198-induced antinociception was determined by giving subjects different doses of s.c. J-113397 (0.01, 0.03, and $0.1 \mathrm{mg} / \mathrm{kg}$ ) for in vivo apparent $\mathrm{pA}_{2}$ analysis. In particular, the dose-response curve of s.c. Ro 64-6198 for antinociception was redetermined $15 \mathrm{~min}$ after pretreatment with a single dose of J-113397. A single dose of naltrexone $(0.03 \mathrm{mg} / \mathrm{kg})$ and J-113397 (0.1 mg/kg) was used to compare their antagonist effects against both alfentanil- and Ro 646198-induced antinociception. The dose and pretreatment time (ie, $15 \mathrm{~min}$ ) for both naltrexone and J-113397 were chosen based on an earlier study (Ko et al, 1998a).

The tail-withdrawal latency in $46^{\circ} \mathrm{C}$ water following $0.1 \mathrm{mg}$ of capsaicin administration was measured to evaluate the potential antiallodynic effects of analgesics (Ko et al, 1998b, 2002b). The procedure for studying thermal allodynia was slightly different from the general procedure for measuring thermal antinociception. The dose-response studies were measured by using a single-dosing procedure. The $46^{\circ} \mathrm{C}$ water was the thermal threshold for these subjects for expressing allodynic responses following the local injection of the capsaicin (Ko et al, 1998b, 2002b). After the chemical was administered s.c. in the tail, it dose-dependently produced thermal allodynia that peaked $15 \mathrm{~min}$ following the injection. This allodynic response was manifested as a reduced tail-withdrawal latency from a maximum value of $20 \mathrm{~s}$ to approximately $2-3 \mathrm{~s}$ in $46^{\circ} \mathrm{C}$ water. The test compounds, Ro 64-6198 and alfentanil, were administered s.c. $15 \mathrm{~min}$ before the capsaicin administration.

\section{Scratching Responses}

Scratching responses, inferred as an itch sensation (Ko et al, 2004), were recorded on videotapes when monkeys were in their home cages. The test compound was administered i.m. by a cumulative dosing procedure with a 30 -min interinjection interval. Each recording session was conducted for $15 \mathrm{~min} /$ test session (ie, from 15 to $30 \mathrm{~min}$ for each drug injection cycle). A scratch was defined as one shortduration $(<1 \mathrm{~s})$ episode of scraping contact of the forepaw or hindpaw on the skin surface of other body parts. Scratching responses were scored by trained individuals who were blinded to experimental conditions. In addition, sedation was monitored by cumulative time for eye closure or lying down at the bottom of the cage. Both scratching 
and sedation end points were summed into one score per session.

\section{Respiratory Function}

The apparatus is similar to that described previously (Butelman et al, 1993). The monkey was seated in a primate restraint chair, enclosed within a sound-attenuating chamber. A rectangular helmet $(13.5 \times 17.0 \times 13.5 \mathrm{~cm})$ was placed over the head of the monkey and sealed around its neck by two closely fitting latex shields. Gas (either air or a mixture of 5\% $\mathrm{CO}_{2}$ in air) flowed into the helmet and was pumped out at a rate of $81 / \mathrm{min}$. The monkeys' breathing produced changes in pressure inside the helmet that were measured with a pressure transducer connected to a polygraph (Grass Model 7). The data were recorded on a polygraph trace and in a microprocessor (IBM PC) through an analog-to-digital converter. The polygraph integrator was connected to a computer, which analyzes the data collected over a 3-min period. The rate of breathing ( $f$, respiratory frequency) is determined directly. The minute volume $\left(V_{\mathrm{E}}\right)$, the number of liters of air inspired per min, is determined from the integration of the plethysmograph system. The test compound was given i.m. in a cumulative dosing procedure, the test session contained 5-6 consecutive cycles of exposure to air. Each cycle was $30 \mathrm{~min}$, which included a 23 -min exposure to air alone and a 7-min exposure to $5 \% \mathrm{CO}_{2}$ mixed in air. The test compound was administered in the beginning of each test cycle and the doses were increased by a 0.25 or $0.5 \log$ unit throughout the test sessions.

\section{Self-Administration}

Three groups of monkeys ( $n=3$ per group), with baselines of either alfentanil, cocaine, or methohexital self-administration were used to evaluate the reinforcing effects of Ro 64-6198. The common elements of the groups were that drug availability was signaled by a red stimulus light in the monkeys' home cages, and a fixed number of responses on a lever located beneath the stimulus light resulted in an infusion of drug or saline. The red light was extinguished and a green light was paired with the infusion. The red light remained off for a brief period after the infusion (timeout), during which time responding on the lever had no programed consequence. Ro 64-6198 or saline was substituted for the baseline drug no more often than once every fourth session; two 2-h sessions were scheduled each day. In the two groups with alfentanil and cocaine baselines, each infusion followed 30 responses, which in turn, was followed by a 45-s timeout. In addition, each session comprised four components, each $25 \mathrm{~min}$ or 20 infusions in duration. The duration of the infusion pump, and therefore, the dose of the drug, was varied across components, so that doseresponse observations could be made in each session (Winger et al, 1992).

A more rigorous evaluation of the reinforcing effects of Ro 64-6198 was made in the monkeys that had sodium methohexital as a baseline drug. In this case, a single dose of drug $(0.1 \mathrm{mg} / \mathrm{kg}$ methohexital as baseline) was available throughout each twice-daily session on an FR 10-60 s schedule. The simpler schedule with a smaller response requirement as well as a comparison with a drug that is less reinforcing than cocaine or alfentanil was used in these animals to increase the possibility of observing a reinforcing effect of Ro 64-6198.

\section{Data Analysis}

Mean values (mean \pm SEM) were calculated from all behavioral endpoint. Comparisons were made for the same monkeys across all test sessions in the same experiment. For the dose-response curves for antinociception, individual tail-withdrawal latencies were converted to percentage of maximum possible effect. The formula of the percentage of maximum possible effect is defined as ((test latency-control latency)/(cutoff latency, $20 \mathrm{~s}$ - control latency)) $\times 100$. $\mathrm{ED}_{50}$ values were calculated by least-squares regression with the portion of the dose-response curves spanning the 50\% maximum possible effect. The $95 \%$ confidence limits were also determined. Mean $\mathrm{ED}_{50}$ values were considered to be significantly different when their $95 \%$ confidence limits did not overlap. For in vivo apparent $\mathrm{pA}_{2}$ analysis (ie, multiple doses of antagonist), dose ratios between dose and response curves were analyzed in a Schild plot, and the mean $\mathrm{J}-113397 \mathrm{pA}_{2}$ value was averaged from the individual values following linear regression lines in the Schild plot. In addition, apparent $\mathrm{pK}_{B}$ values were determined for a single dose of antagonist by using a modified equation, $\mathrm{pK}_{B}=-\log (B /($ dose ratio -1$))$, where $B$ equals the antagonist dose in moles $/ \mathrm{kg}$. Mean $\mathrm{pK}_{B}$ values $\pm 95 \%$ confidence limits were averaged from individual $\mathrm{pK}_{B}$ values for J-113397 and naltrexone.

Mean number of injections earned or response rates for each dose of self-administered drug were calculated by averaging the results of each substitution trial for a given dose across all experimental subjects. The one-way ANOVA was conducted for data obtained from scratching, respiration, and self-administration experiments. Where appropriate, post hoc comparisons using the Tukey's test were made between the drug effect and the vehicle effect. The criterion for significance was set at $P<0.05$.

\section{Drugs}

Alfentanil $\mathrm{HCl}$, naltrexone $\mathrm{HCl},(-)$ cocaine $\mathrm{HCl}$, and $(+) \mathrm{J}-$ 113397, provided by the National Institute on Drug Abuse (Bethesda, MD), were dissolved in sterile water. Ro 64-6198, provided by F. Hoffmann-La Roche AG (Basel, Switzerland), was dissolved in a solution of DMSO/Tween $80 /$ sterile water in a ratio of 1:1:8. Capsaicin (Sigma, St Louis, MO) was dissolved in a solution of ethanol/Tween80/ saline in a ratio of $1: 1: 8$, and it was administered s.c. in the terminal $3-6 \mathrm{~cm}$ of the tail with constant $0.1 \mathrm{ml}$ volume. Methohexital, purchased from Ace Surgical Supplies (Brockton, MA), was diluted with sterile water. Doses are presented in the compound forms listed above. For systemic administration in antinociception, scratching, and respiration experiments, all test compounds were administered at a volume of $0.1 \mathrm{ml} / \mathrm{kg}$.

\section{RESULTS}

Figure 1 illustrates the antagonist effect of J-113397 against Ro 64-6198-induced antinociception in $50^{\circ} \mathrm{C}$ water. 

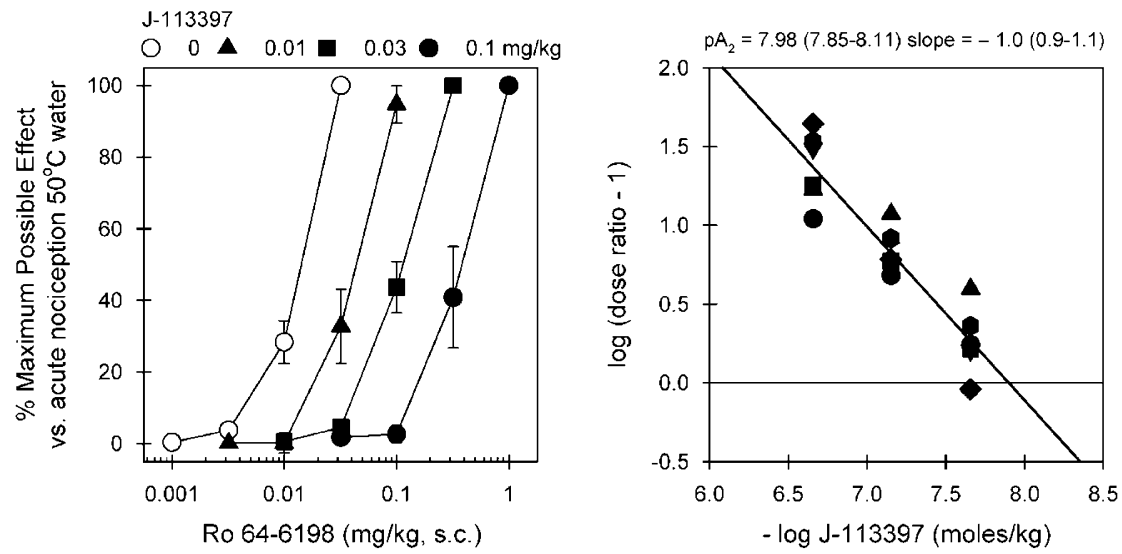

Figure I In vivo antagonist potency of J-I I 3397 against Ro 64-6198-induced antinociception in monkeys. Left panel, antagonist effects of s.c. J- I I 3397 on the dose-response curve of Ro 64-6198-induced antinociception in $50^{\circ} \mathrm{C}$ water. Each data point represents a mean \pm SEM $(n=6)$. Right panel, a Schild plot for J-I I 3397. Abscissa, negative log unit for J-I 13397 in moles $/ \mathrm{kg}$. Ordinate, log of (dose ratio: I). Each point was converted from individual dose ratio for each dosing condition presented in the left panel. Closed symbols represent different subjects. The mean $\mathrm{pA}_{2}$ value and slope of J-I I 3397 are shown with 95\% confidence limits in parentheses.
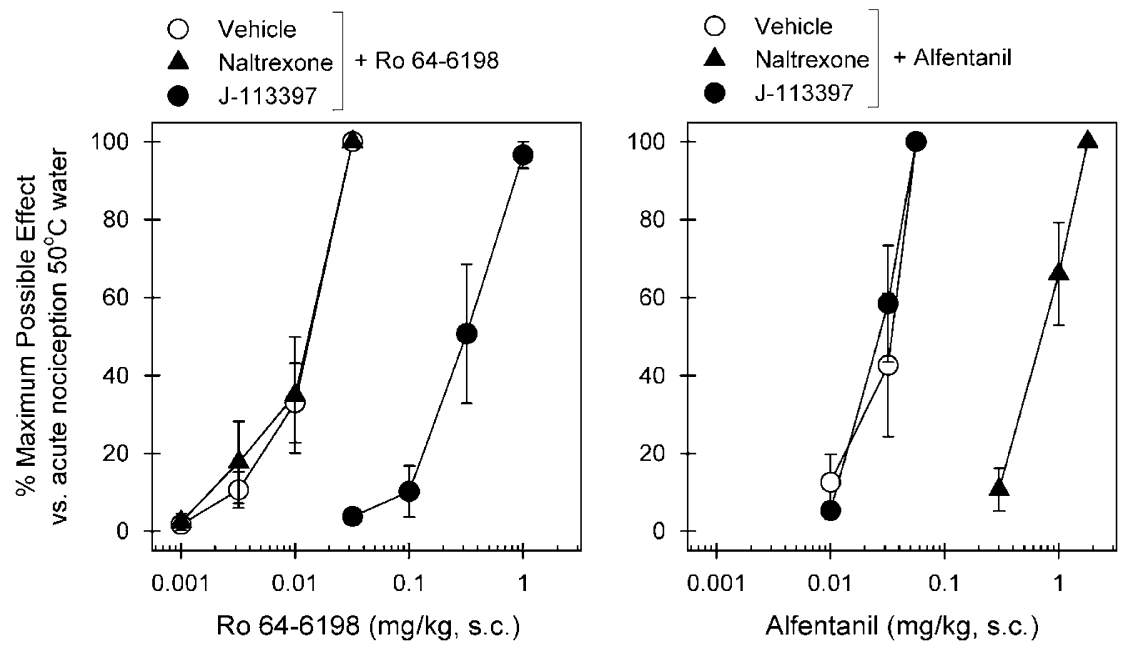

Figure 2 Effects of $\mu$-opioid receptor and NOP receptor antagonists on alfentanil- and Ro 64-6198-induced antinociceptive effects in monkeys. A $\mu$-opioid receptor antagonist (naltrexone, $0.03 \mathrm{mg} / \mathrm{kg}, \mathrm{s.c}$.) or an NOP receptor antagonist (J-I I 3397, $0.1 \mathrm{mg} / \mathrm{kg}$, s.c.) was administered s.c. $15 \mathrm{~min}$ before redetermination of the dose-response curve of alfentanil and Ro 64-6198. Left panel, antagonist effects of s.c. naltrexone and J-II3397 on the doseresponse curve of Ro 64-6198-induced antinociception in $50^{\circ} \mathrm{C}$ water. Right panel, antagonist effects of s.c. naltrexone and J-I I 3397 on the dose-response curve of alfentanil-induced antinociception in $50^{\circ} \mathrm{C}$ water. Each data point represents a mean $\pm \operatorname{SEM}(n=6)$.

Mean $\mathrm{ED}_{50}$ (95\% confidence limit) value of s.c. Ro 64-6198induced antinociception with vehicle pretreatment was $0.014 \mathrm{mg} / \mathrm{kg}$ (0.011-0.016). Pretreatment with J-113397 dose-dependently produced rightward shifts of the doseresponse curve of Ro 64-6198-induced antinociception. These dose-dependent antagonist effects of J-113397 were graphed in a Schild plot with values derived from individual dose ratios for each subject. The mean $\mathrm{pA}_{2}$ value of J-113397 was $7.98(7.85-8.11)$ with a slope of -1 . The doses of J-113397 alone did not change the thermal threshold of monkeys (ie, no changes in the tail-withdrawal latencies in 42,46 , or $50^{\circ} \mathrm{C}$ water).

Figure 2 compares the antagonist effects of naltrexone and J-113397 on the antinociceptive effects produced by s.c. Ro 64-6198 and alfentanil. The left panel shows that a single dose $(0.1 \mathrm{mg} / \mathrm{kg})$ of $\mathrm{J}-113397$ produced a large rightward shift of the dose-response curve of Ro 64-6198-induced antinociception. The mean $\mathrm{J}-113397 \mathrm{pK}_{B}$ value was 8.02
(7.78-8.26) under this condition. Naltrexone $0.03 \mathrm{mg} / \mathrm{kg}$ failed to block Ro 64-6198-induced antinociception; the $\mathrm{ED}_{50}$ value of Ro 64-6198 dose-response for vehicle pretreatment $(0.012 \mathrm{mg} / \mathrm{kg})$ was similar to that for naltrexone pretreatment $(0.013 \mathrm{mg} / \mathrm{kg})$. In contrast, the right panel shows that a single dose of naltrexone $0.03 \mathrm{mg} / \mathrm{kg}$ produced a large rightward shift of the dose-response curve of alfentanil-induced antinociception. The mean naltrexone $\mathrm{pK}_{B}$ value was $8.44(8.18-8.70)$ under this condition. $\mathrm{J}-1133970.1 \mathrm{mg} / \mathrm{kg}$ failed to block alfentanil-induced antinociception; the $\mathrm{ED}_{50}$ value of alfentanil dose-response for vehicle pretreatment $(0.031 \mathrm{mg} / \mathrm{kg})$ was similar to that for $\mathrm{J}-113397$ pretreatment $(0.026 \mathrm{mg} / \mathrm{kg})$.

Figure 3 illustrates the antinociceptive effects of Ro 646198 and alfentanil against capsaicin-induced allodynia. Normally, monkeys kept their tails in $46^{\circ} \mathrm{C}$ water for $20 \mathrm{~s}$, but withdrew their tails within $1-3 \mathrm{~s}$ after capsaicin injection (mean \pm SEM, $1.7 \pm 0.2 \mathrm{~s}$ ). Pretreatment with Ro 64-6198 

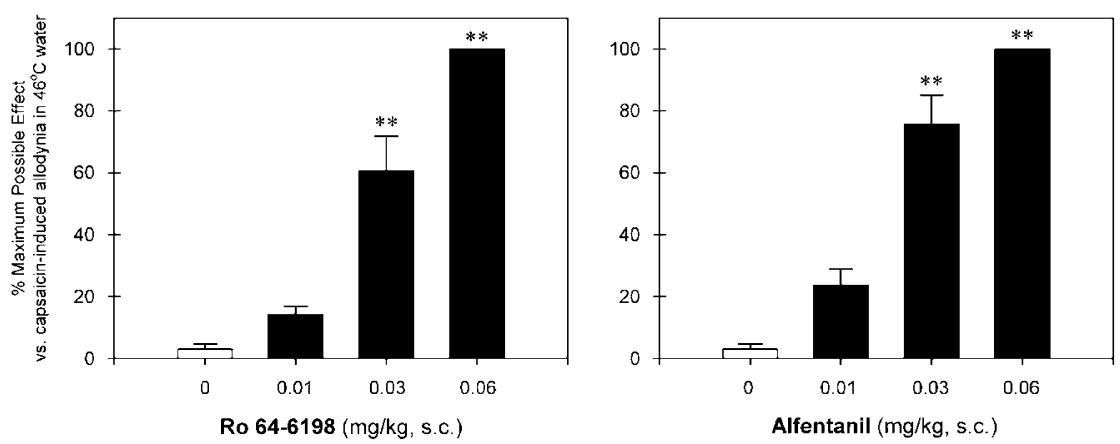

Figure 3 Antinociceptive effects of Ro 64-6198 and alfentanil against capsaicin-induced allodynia in $46^{\circ} \mathrm{C}$ water. Each data point represents a mean \pm SEM $(n=6)$. The asterisks represent a significant difference from the vehicle condition $(* * p<0.0 \mathrm{I})$. Each data point was measured at I 5 min after administration of capsaicin.

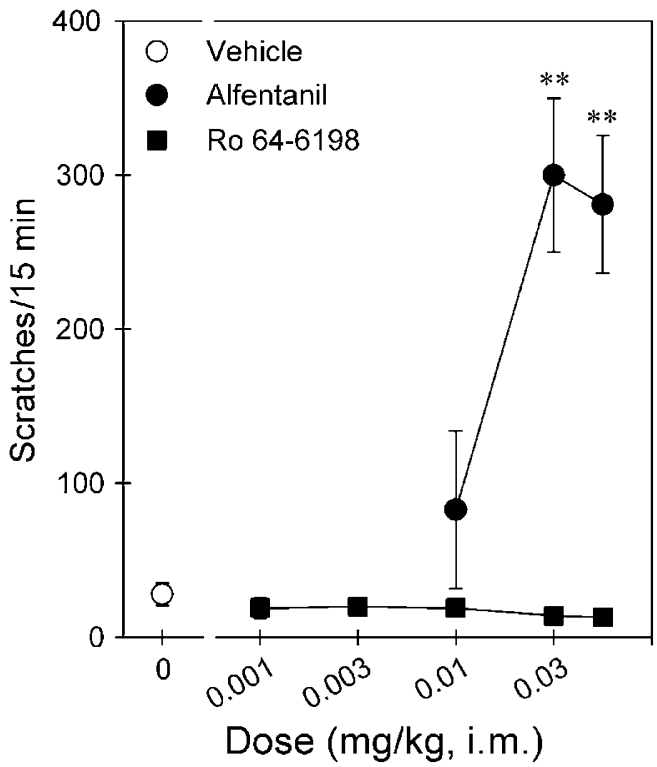

Figure 4 Comparison of the dose-response curves for itch/scratching effects produced by i.m. administration of alfentanil and Ro 64-6198. Each data point represents a mean $\pm \operatorname{SEM}(n=6)$. The asterisks represent a significant difference from the vehicle condition $(* * p<0.0$ l).

$(\mathrm{F}(3,20)=60.6 ; \quad p<0.01)$ and alfentanil $(\mathrm{F}(3,20)=68.3$; $p<0.01)$ both dose-dependently attenuated allodynia in $46^{\circ} \mathrm{C}$ water. The $\mathrm{ED}_{50}$ value for Ro 64-6198 dose-response $(0.024 \mathrm{mg} / \mathrm{kg})$ was similar to that for alfentanil $(0.019 \mathrm{mg} /$ $\mathrm{kg}$ ) under this condition.

Figure 4 compares the itch/scratching responses of alfentanil and Ro 64-6198 after i.m. administration. Alfentanil produced a dose-dependent increase in scratching $(\mathrm{F}(3,20)=11.0 ; p<0.05)$. Post hoc comparisons indicated that both doses of alfentanil 0.03 and $0.06 \mathrm{mg} / \mathrm{kg}$ significantly increased scratching responses $(p<0.01)$. The peak effect was $300 \pm 49.9$ (mean \pm SEM) scratches evoked by $0.03 \mathrm{mg} / \mathrm{kg}$ of alfentanil. In contrast, Ro 64-6198 did not increase scratching responses $(\mathrm{F}(5,30)=0.7 ; p>0.05)$, compared with the vehicle condition in the same monkeys. These doses of Ro 64-6198 (ie, $0.001-0.06 \mathrm{mg} / \mathrm{kg}$ ) did not produce any observable sedation in monkeys.
Figure 5 compares the respiratory depressant effects of alfentanil and Ro 64-6198 after i.m. administration. The top panels show the dose-response curves of alfentanil and Ro 64-6198 for the changes of respiratory parameters $f$ and $V_{\mathrm{E}}$ during air breathing. Alfentanil produced dose-dependent changes for both $f(\mathrm{~F}(4,25)=3.3 ; p<0.05)$ and $V_{\mathrm{E}}$ $(\mathrm{F}(4,25)=9.3 ; p<0.05]$. Post hoc comparisons indicated that alfentanil $0.06 \mathrm{mg} / \mathrm{kg}$ significantly decreased $f$ responses $(p<0.05)$. In addition, both doses of alfentanil, 0.03 and $0.06 \mathrm{mg} / \mathrm{kg}$, significantly decreased $V_{\mathrm{E}}$ responses $(p<0.05)$. The maximum depressant effect of $\mathrm{V}_{E}$ responses produced by alfentanil $0.06 \mathrm{mg} / \mathrm{kg}$ was $55 \pm 5 \%$ of control response (ie, before drug administration). In contrast, Ro 64-6198 did not decrease the respiratory function manifested by $f(\mathrm{~F}(5,30)=0.2 ; \quad p>0.05)$ and $V_{E}$ $(\mathrm{F}(5,30)=1.4 ; p>0.05)$ responses, compared with the vehicle condition in the same monkeys.

The bottom panels show the dose-response curves of alfentanil and Ro 64-6198 for the changes of respiratory parameters $f$ and $V_{E}$ during breathing of a mixture of $5 \%$ $\mathrm{CO}_{2}$ in air. This increase in $\mathrm{CO}_{2}$ enhances the sensitivity of the assay to the potential respiratory depressant effects of test compounds. Alfentanil produced dose-dependent changes of both $f(\mathrm{~F}(4,25)=14.1 ; p<0.05)$ and $V_{E}$ $(\mathrm{F}(4,25)=19.4 ; p<0.05)$ under these conditions. Post hoc comparisons indicated that both alfentanil 0.03 and $0.06 \mathrm{mg} / \mathrm{kg}$ significantly decreased $f$ and $V_{E}$ responses $(p<0.05)$. The maximum respiratory depressant effect produced by alfentanil $0.06 \mathrm{mg} / \mathrm{kg}$ was $67 \pm 3$ and $46 \pm 4 \%$ of control $f$ and $V_{E}$ responses, respectively. In contrast, Ro 64-6198 did not significantly decrease the respiratory parameters $f(\mathrm{~F}(5,30)=1.3 ; p>0.05)$ and $V_{E}(\mathrm{~F}(5,30)=2.4$; $p>0.05)$, compared with the vehicle condition in the same monkeys.

Figure 6 top panel shows the reinforcing effects of Ro 64-6198 in alfentanil-maintained monkeys. Response rates (responses/s) for saline, alfentanil, and Ro 64-6198 across a dose range of $0.03-30 \mu \mathrm{g} / \mathrm{kg}$ per injection were assessed. To aggregate data across all three subjects, mean response rates engendered by each dose of each drug were averaged. Under the multiple component schedules, contingent saline infusions engendered very low response rates $(<0.3$ responses/s). The top panel of Figure 6 presents the aggregate dose-response curves for alfentanil and Ro 646198. All animals self-administered alfentanil within the 

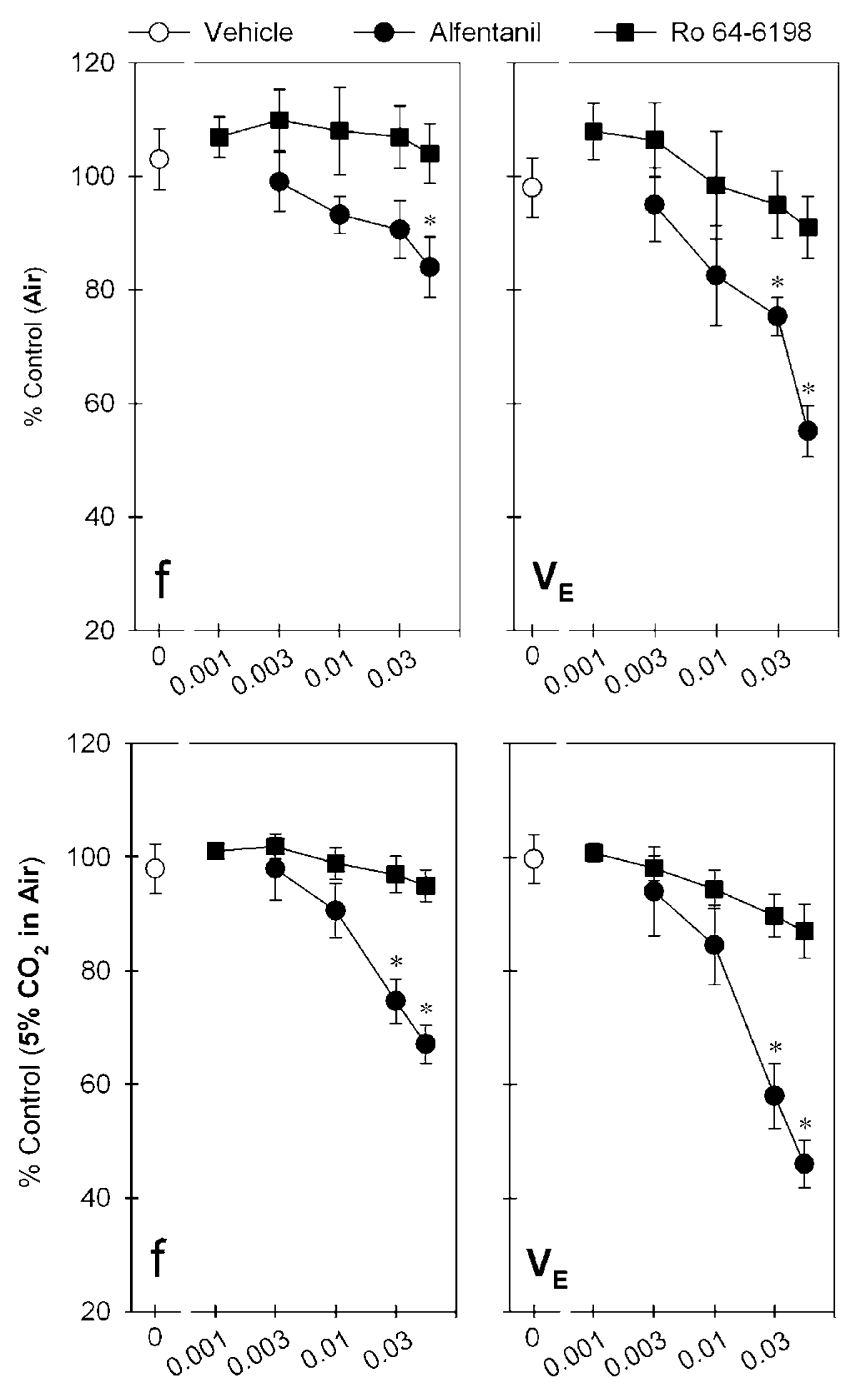

Dose (mg/kg, i.m.)

Figure 5 Comparison of the dose-response curves for respiratory depressant effects produced by i.m. administration of alfentanil and Ro 646198. Top and bottom panels show the changes of both $f$ and $V_{E}$ parameters when monkeys breathing air and air mixed with $5 \%$ $\mathrm{CO}_{2}$,respectively. Each data point represents a mean $\pm \operatorname{SEM}(n=6)$. The asterisk represent a significant difference from the vehicle condition $(* 0<0.05)$.

dose range tested, generating a biphasic dose-effect curve characteristic of i.v. drug self-administration. In contrast, Ro 64-6198 did not maintain high rates of responding at any of the doses tested, resulting in a flat dose-effect curve indicative of a compound without reinforcing effects under the present conditions. Likewise, the middle panel indicates that Ro 64-6198 did not maintain high rates of responding at the doses tested, although all subjects self-administered cocaine under the same schedule.

Figure 6 bottom panel presents the aggregate doseresponse curves for Ro 64-6198 compared with responding maintained by a reference dose of methohexital or saline. The number of injections earned of Ro 64-6198 across a dose range of $1-30 \mu \mathrm{g} / \mathrm{kg}$ per injection were compared to the number of self-injections earned of $0.1 \mathrm{mg}$ per $\mathrm{kg} /$ injection methohexital or saline. To aggregate data across all three
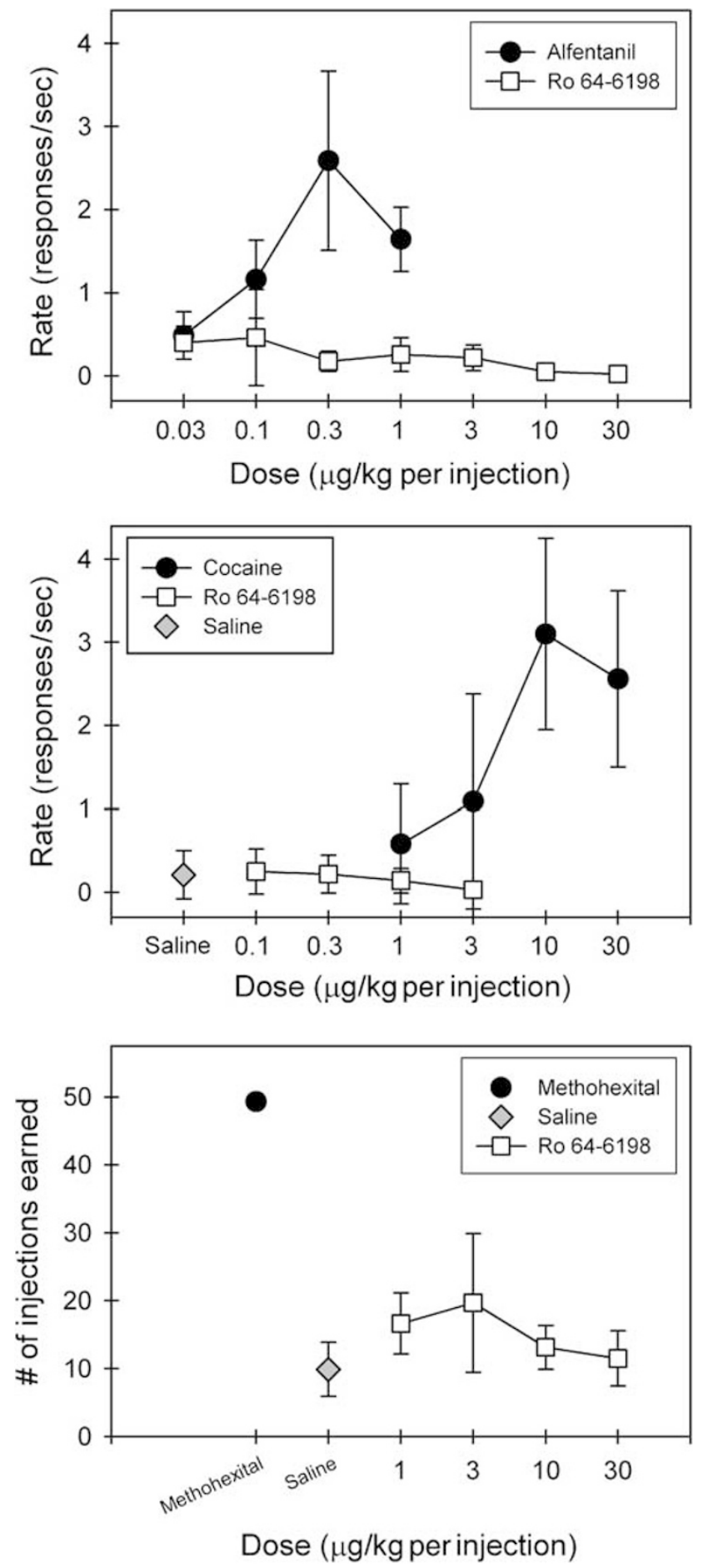

Figure 6 Lack of reinforcing effects of Ro 64-6198 in alfentanil-, cocaine-, and methohexital-maintained monkeys. Top and middle panels: Symbols represent aggregated dose-response curves for alfentanil, cocaine, and Ro 64-6198 under a fixed ratio of 30 timeout $45 \mathrm{~s}$ multiple component schedule. Data are the means $\pm \operatorname{SEM}(n=3)$ for the response rates. Bottom panel: symbols represent aggregated dose-response curves for Ro 64-6198 compared with responding maintained by a single dose of methohexital $0.1 \mathrm{mg} / \mathrm{kg} /$ injection or saline. Data are the means \pm SEM $(n=3)$ for the numbers of injection earned.

experimental animals, mean number of injections earned by each monkey at each dose were averaged. Methohexitalmaintained responding occurred at a high, regular rate 
across the entire session. When contingent saline was available, animals tended to 'sample' early in the session, but behavior generally abated entirely within $15 \mathrm{~min}$. No dose of Ro 64-6198 reliably maintained responding above levels observed when saline was available, indicating that Ro 64-6198 had no reinforcing effects under the present conditions.

\section{DISCUSSION}

Systemic Ro 64-6198 alone produced antinociceptive effects that were blocked dose-dependently by J-113397, a selective NOP receptor antagonist. In vivo apparent $\mathrm{pA}_{2}$ analysis was used because this quantitative procedure offers a powerful approach to establish receptor-mediated drug effects (Arunlakshana and Schild, 1959; Tallarida et al, 1979). In this study, J-113397 dose-dependently produced parallel rightward shifts of the dose-response curve of Ro 64-6198induced antinociception (Figure 1), indicating that the agonist and antagonist compete for the same NOP receptors in a reversible manner. The $\mathrm{pA}_{2}$ value of $\mathrm{J}-113397,8.0$, was approximately threefold less than the naltrexone $\mathrm{pA}_{2}$ value of 8.5 under the same behavioral context using an antinociceptive assay (Ko et al, 1998a), indicating that both naltrexone and J-113397 are potent antagonists in vivo for $\mu$-opioid and NOP receptors, respectively, in monkeys. More important, examination of both antagonists against different agonists showed that alfentanil- and Ro 64-6198induced antinociceptive effects were mediated by $\mu$-opioid receptors and NOP receptors, respectively (Figure 2). J-113397 $0.1 \mathrm{mg} / \mathrm{kg}$ failed to block alfentanil-induced antinociception and naltrexone $0.03 \mathrm{mg} / \mathrm{kg}$ failed to block Ro 64-6198-induced antinociception. These results indicate that antinociceptive effects of opioid analgesics are produced by two independent opioid receptor mechanisms in monkeys.

Systemic administration of Ro 64-6198-produced antinociception against capsaicin-induced allodynia in monkeys (Figure 3). Capsaicin evokes pain sensation by activating at the vanilloid receptor and stimulating the release of pronociceptive neuropeptides, such as substance $P$ from primary afferents (Szallasi et al, 2007). Studies have shown that the vanilloid receptor is required for inflammatory sensitization to noxious stimuli and is essential for tissue injury-induced allodynia and hyperalgesia (Caterina et al, 2000; Davis et al, 2000). Capsaicin-induced allodynia has been used in both monkeys (Ko et al, 1998b; Butelman et al, 2004) and humans (Park et al, 1995; Eisenach et al, 1997) to show its prominent value for studying pain mechanisms in vivo and pharmacological interventions. Given that capsaicin-sensitive nerve fibers are involved in a variety of nociceptive conditions (Szallasi et al, 2007), the effectiveness of Ro 64-6198 in inhibiting capsaicin-induced allodynia indicates that NOP receptor agonists may be effective for treating pain derived from different nociceptive origins.

It is worth noting that systemic Ro 64-6198 did not produce antinociceptive effects in rodents (Jenck et al, 2000). Perhaps supraspinal NOP receptor-mediated hyperalgesia in rodents (Meunier et al, 1995; Rizzi et al, 2007) counteract antinociceptive effects mediated by spinal and peripheral NOP receptors when rodents receive systemic administration of non-peptidic NOP receptor agonists. Given that both systemic and spinal administration routes are commonly used for delivery of analgesics in humans, it may not be practical to study the effects of intracerebroventricular administration of NOP receptor agonists in monkeys. Nevertheless, the degree of integrated physiological outcome from activating supraspinal, spinal, and peripheral NOP receptors together following systemic administration of NOP receptor agonists may vary across species. Anatomical studies have indicated that differences between rodents and primates may exist in the distribution of N/OFQ and NOP receptors (Berthele et al, 2003; Bridge et al, 2003). In addition, functional studies have also revealed that species differences exist in the pharmacological profiles of spinal N/OFQ between rodents and primates (Inoue et al, 1999; Sakurada et al, 1999). Unlike dual actions (ie, both pronociceptive and antinociceptive effects) of intrathecal N/OFQ observed in rodents, intrathecal N/OFQ only produced antinociceptive effects in monkeys (Ko and Naughton, 2009). More research should be conducted to elucidate whether the signal transduction pathways of NOP receptors or/and functions of sensory neurons expressing NOP receptors are different between rodents and primates.

The antinociceptive doses of systemic Ro 64-6198 (ie, $0.01-0.06 \mathrm{mg} / \mathrm{kg}$ ) did not produce undesirable side effects compared with the $\mu$-opioid agonist alfentanil (Figures 3 and 4). Both respiratory depression and itch/scratching have been documented as physiological responses to $\mu$ opioid receptor activation in monkeys (Butelman et al, 1993; Ko et al, 2004). Given that these doses of Ro 64-6198 did not produce any sedation or motor dysfunction in monkeys, systemic Ro 64-6198 provides a promising pharmacological profile of NOP receptors as a novel analgesic in primates. On the other hand, rodent studies have found that higher doses of systemic Ro 64-6198 $(10 \mathrm{mg} / \mathrm{kg}$ ) interfered with behavioral performance (Jenck et al, 2000; Shoblock, 2007). These results suggest that Ro 64-6198 may have a wide therapeutic window between the antinociceptive doses and doses eliciting undesirable side effects. Whereas this study suggests that Ro 64-6198 may have a wide therapeutic index relative to the $\mu$-opioid agonist alfentanil, it does not establish what the doselimiting effects of this compound might be. Administration of larger doses of Ro 64-6198 and other systemically active NOP receptor agonists are needed to establish dose-limiting effects.

No reinforcing effects of Ro 64-6198 in alfentanil-, cocaine-, and methohexital-maintained monkeys (Figure 6) were observed. The presence of a behavioral effect (ie, antinociception at $10-30 \mu \mathrm{g} / \mathrm{kg}$ ) in the absence of any indication of a reinforcing effect indicates that we have tested sufficiently large doses for potential reinforcing effects. For example, the antinociceptive doses of i.v. alfentanil were $10-30 \mu \mathrm{g} / \mathrm{kg}$ (Ko et al, 2002a), but the doses of alfentanil-producing reinforcing effects were $0.1-1 \mu \mathrm{g} / \mathrm{kg}$ (ie, a 30-100-fold difference; Winger et al, 1992; Ko et al, 2002a). Lack of reinforcing effects by Ro 64-6198 might be expected because several studies have shown that the activation of NOP receptors inhibited dopamine release in the striatum, and supported the notion that NOP receptor 
agonists do not have reinforcing or aversive properties of their own (Murphy and Maidment, 1999; Flau et al, 2002). Given that increased dopamine neuronal activity is closely associated with reinforcing effects of several drugs of abuse, it will be valuable to study further whether NOP receptor agonists can suppress the reinforcing effects of other drugs that have abuse potential in primates.

Taken together, this study showed that antinociceptive effects of systemic Ro 64-6198 were independent of $\mu$-opioid receptors and activation of NOP receptors produced antinociception without reinforcing effects in monkeys. Ro 64-6198 has previously been studied in only rodent species (Chiou et al, 2007; Shoblock, 2007). This is the first study to investigate the behavioral effects of Ro 646198 in primates. Like alfentanil, Ro 64-6198 produced antinociception in two primate nociceptive models. Unlike alfentanil, Ro 64-6198 did not produce reinforcing effects, respiratory depressant, or itch/pruritic side effects, indicating that NOP receptor agonists may be a new generation of novel analgesics without abuse liability. Such a promising pharmacological profile warrants additional studies to document potential therapeutic value of NOP receptor agonists in humans.

\section{ACKNOWLEDGEMENTS}

We thank Dr Gail Winger for her assistance with the editing of manuscript and John Busenbark, Tristan Edwards, and Wayne Yang for excellent technical assistance. This study was supported by the US Department of Defense, Peer Reviewed Medical Research Program, Grant W81XWH-071-0162 to Mei-Chuan Ko and the US Public Health Service Grant DA-015449 to Gail Winger.

\section{DISCLOSURE/CONFLICT OF INTEREST}

The authors declare that, except for income received from their primary employer, no financial support or compensation has been received from any individual or corporate entity over the past 3 years for research or professional service except as listed below, and there are no personal financial holdings that could be perceived as constituting a potential conflict of interest. The author MCK received research support from Grunenthal $\mathrm{GmbH}$, Ingenium Pharmaceuticals, Amgen, SSV Therapeutics, and Elan Pharmaceuticals. The author JHW received research support from Grunenthal $\mathrm{GmbH}$, Alkermes, Roche, Adolor Corporation, and Reckitt Benckiser Pharmaceuticals.

\section{REFERENCES}

Arunlakshana O, Schild HO (1959). Some quantitative uses of drug antagonists. Br J Pharmacol 14: 48-58.

Ator NA, Griffiths RR (1987). Self-administration of barbiturates and benzodiazepines: a review. Pharmacol Biochem Behav 27: 391-398.

Berthele A, Platzer S, Dworzak D, Schadrack J, Mahal B, Butter A et al (2003). [3H]-Nociceptin ligand-binding and nociception opioid receptor mRNA expression in the human brain. Neuroscience 121: 629-640.

Bridge KE, Wainwright A, Reilly K, Oliver KR (2003). Autoradiographic localization of 125I[Tyr14]nociception/orphanin FQ binding sites in macaque primate CNS. Neuroscience 118: 513-523.

Butelman ER, France CP, Woods JH (1993). Apparent $\mathrm{pA}_{2}$ analysis on the respiratory depressant effects of alfentanil, etonitazene, ethylketocyclazocine(EKC) and Mr2033 in rhesus monkeys. J Pharmacol Exp Ther 264: 145-151.

Butelman ER, Harris TJ, Kreek MJ (2004). Antiallodynic effects of loperamide and fentanyl against topical capsaicin-induced allodynia in unanesthetized primates. J Pharmacol Exp Ther 311: 155-163.

Caterina MJ, Leffler A, Malmberg AB, Martin WJ, Trafton J, Petersen-Zeitz KR et al (2000). Impaired nociception and pain sensation in mice lacking the capsaicin receptor. Science 288: 306-313.

Chiou LC, Liao YY, Fan PC, Kuo PH, Wang CH, Riemer C et al (2007). Nociceptin/orphanin FQ peptide receptors: pharmacology and clinical implications. Curr Drug Targets 8: 117-135.

Cicero TJ, Dart RC, Inciardi JA, Woody GE, Schnoll S, Munoz A (2007). The development of a comprehensive risk-management program for prescription opioid analgesics: researched abuse, diversion and addiction-related surveillance (RADARS). Pain Med 8: 157-170.

Davis JB, Gray J, Gunthorpe MJ, Hatcher JP, Davey PT, Overend P et al (2000). Vanilloid receptor-1 is essential for inflammatory thermal hyperalgesia. Nature 405: 183-187.

Dykstra LA, Gmerek DE, Winger G, Woods JH (1987). Kappa opioids in rhesus monkeys. I. Diuresis, sedation, analgesia and discriminative stimulus effects. J Pharmacol Exp Ther 242: 413-420.

Eisenach JC, Hood DD, Curry R, Tong C (1997). Alfentanil, but not amitriptyline, reduces pain, hyperalgesia, and allodynia from intradermal injection of capsaicin in humans. Anesthesiology 86: 1279-1287.

Erb K, Liebel JT, Tegeder I, Zeilhofer HU, Brune K, Geisslinger G (1997). Spinally delivered nociceptin/orphanin FQ reduces flinching behaviour in the rat formalin test. Neuroreport 8: 1967-1970.

Flau K, Redmer A, Liedtke S, Kathmann M, Schlicker E (2002). Inhibition of striatal and retinal dopamine release via nociceptin/orphanin FQ receptors. Br J Pharmacol 137: 1355-1361.

Foord SM, Bonner TI, Neubig RR, Rosser EM, Pin J-P, Davenport AP et al (2005). International Union of Pharmacology. XLVI. G Protein-Coupled Receptor List. Pharmacol Rev 57: 279-288.

Inoue $\mathrm{M}$, Shimohira I, Yoshida A, Zimmer A, Takeshima H, Sakurada T et al (1999). Dose-related opposite modulation by nociceptin/orphanin FQ of substance $\mathrm{P}$ nociception in the nociceptors and spinal cord. J Pharmacol Exp Ther 291: 308-313.

Jenck F, Wichmann J, Dautzenberg FM, Moreau JL, Ouagazzal AM, Martin JR et al (2000). A synthetic agonist at the orphanin FQ/ nociceptin receptor ORL1: Anxiolytic profile in the rat. Proc Natl Acad Sci USA 97: 4938-4943.

Katz NP, Adams EH, Benneyan JC, Birnbaum HG, Budman SH, Buzzeo RW et al (2007). Foundations of opioid risk management. Clin J Pain 23: 103-118.

Kawamoto H, Ozaki S, Itoh Y, Miyaji M, Arai S, Nakashima H et al (1999). Discovery of the first potent and selective small molecule opioid receptor-like (ORL1) antagonist: 1-[(3R,4R)-1-cyclooctylmethyl-3- hydroxymethyl-4-piperidyl]-3-ethyl-1, 3-dihydro2H-benzimidazol-2-one (J-113397). J Med Chem 42: 5061-5063.

Ko MC, Butelman ER, Traynor JR, Woods JH (1998a). Differentiation of kappa opioid agonist-induced antinociception by naltrexone apparent $\mathrm{pA}_{2}$ analysis in rhesus monkeys. $J$ Pharmacol Exp Ther 285: 518-526.

Ko MC, Butelman ER, Woods JH (1998b). The role of peripheral $\mathrm{mu}$ opioid receptors in the modulation of capsaicin-induced thermal nociception in rhesus monkeys. J Pharmacol Exp Ther 286: $150-156$. 
Ko MC, Naughton NN (2009). Antinociceptive effects of nociception/orphanin FQ administered intrathecally in monkeys. J Pain (in press) doi: 10.1016/j.pain.2008.11.006.

Ko MC, Terner J, Hursh S, Woods JH, Winger G (2002a). Relative reinforcing effects of three opioids with different durations of action. J Pharmacol Exp Ther 301: 698-704.

Ko MCH, Naughton NN, Traynor JR, Song MS, Woods JH, Rice KC et al (2002b). Orphanin FQ inhibits capsaicin-induced thermal nociception in monkeys by activation of peripheral ORL1 receptors. Br J Pharmacol 135: 943-950.

Ko MCH, Song MS, Edwards T, Lee H, Naughton NN (2004). The role of central mu opioid receptors in opioid-induced itch in primates. J Pharmacol Exp Ther 310: 169-176.

Ko MCH, Wei H, Woods JH, Kennedy RT (2006). Effects of intrathecally administered nociceptin/orphanin FQ in monkeys: Behavioral and mass spectrometric studies. J Pharmacol Exp Ther 318: 1257-1264.

Kuhar MJ, Pert CB, Snyder SH (1973). Regional distribution of opiate receptor binding in monkey and human brain. Nature 245: 447-450.

Mansour A, Khachaturian H, Lewis ME, Akil H, Watson SJ (1988). Anatomy of CNS opioid receptors. Tr Neurosci 11: 308-314.

Meunier JC, Mollereau C, Toll L, Suaudeau C, Moisand C, Alvinerie $\mathrm{P}$ et al (1995). Isolation and structure of the endogenous agonist of opioid receptor-like ORL1 receptor. Nature 377: 532-535.

Mollereau C, Parmentier M, Mailleux P, Butour JL, Moisand C, Chalon $\mathrm{P}$ et al (1994). ORL1, a novel member of the opioid receptor family. Cloning, functional expression and localization. FEBS Lett 341: 33-38.

Murphy NP, Maidment NT (1999). Orphanin FQ/nociceptin modulation of mesolimbic dopamine transmission determined by microdialysis. J Neurochem 73: 179-186.

Negus SS, Gatch MB, Mello NK, Zhang X, Rice K (1998). Behavioral effects of the delta-selective opioid agonist SNC80 and related compounds in rhesus monkeys. J Pharmacol Exp Ther 286: 362-375.

Obara I, Przewlocki R, Przewlocka B (2005). Spinal and local peripheral antiallodynic activity of Ro 64-6198 in neuropathic pain in the rat. Pain 116: 17-25.

Park KM, Max MB, Robinovitz E, Gracely RH, Bennett GJ (1995). Effects of intravenous ketamine, alfentanil, or placebo on pain, pinprick hyperalgesia, and allodynia produced by intradermal capsaicin in human subjects. Pain 63: 163-172.

Peckys D, Landwehrmeyer GB (1999). Expression of $\mathrm{mu}$, kappa, and delta opioid receptor messenger RNA in the human CNS: a 33P in situ hybridization study. Neuroscience 88: 1093-1135.

Reinscheid RK, Nothacker HP, Bourson A, Ardati A, Henningsen RA, Bunzow JR et al (1995). Orphanin FQ: a neuropeptide that activates an opioidlike G protein-coupled receptor. Science 270: 792-794.

Rizzi A, Spagnolo B, Wainford RD, Fischetti C, Guerrini R, Marzola $\mathrm{G}$ et al (2007). In vitro and in vivo studies on UFP-112, a novel potent and long lasting agonist selective for the nociceptin/orphanin FQ receptor. Peptides 28: 1240-1251.

Sakurada T, Katsuyama S, Sakurada S, Inoue M, Tan-No K, Kisara $\mathrm{K}$ et al (1999). Nociceptin-induced scratching, biting, and licking in mice: involvement of spinal NK1 receptors. $\mathrm{Br} J$ Pharmacol 127: $1712-1718$.

Shoblock JR (2007). The pharmacology of Ro 64-6198, a systemically active, nonpeptide NOP receptor (opiate receptorlike 1, ORL1) agonist with diverse preclinical therapeutic activity. CNS Drug Rev 13: 107-136.

Szallasi A, Cortright DN, Blum CA, Eid SR (2007). The vanilloid receptor TRPV1: 10 years from channel cloning to antagonist proof of concept. Nat Rev Drug Discov 6: 357-372.

Tallarida RJ, Cowan A, Adler MW (1979). pA2 and receptor differentiation: a statistical analysis of competitive antagonism. Life Sci 25: 637-654.

Weerts EM, Fantegrossi WE, Goodwin AK (2007). The value of nonhuman primates in drug abuse research. Exp Clin Psychopharmacol 15: 309-327.

Wichmann J, Adam G, Rover S, Hennig M, Scalone M, Cesura AM et al (2000). Synthesis of (1S,3aS)-8-(2,3,3a,4,5, 6-hexahydro- $1 \mathrm{H}-$ phenalen-1-yl)-1-phenyl-1,3,8-triaza-spiro[4. 5]decan-4-one, a potent and selective orphanin FQ (OFQ) receptor agonist with anxiolytic-like properties. Eur J Med Chem 35: 839-851.

Winger G, Skjoldager P, Woods JH (1992). Effects of buprenorphine and other opioid agonists and antagonists on alfentaniland cocaine-reinforced responding in rhesus monkeys. J Pharmacol Exp Ther 261: 311-317.

Winger G, Stitzer ML, Woods JH (1975). Barbiturate-reinforced responding in rhesus monkeys: comparisons of drugs with different durations of action. J Pharmacol Exp Ther 195 505-514.

Zeilhofer HU, Calo G (2003). Nociceptin/orphanin FQ and its receptor-potential targets for pain therapy? J Pharmacol Exp Ther 306: 423-429.

Zollner C, Stein C (2007). Opioids. Handb Exp Pharmacol 177: 31-63. 